\title{
Trade and InVEstment under Floating RATES: THE U.S. EXPERIENCE
}

\author{
Martin J. Bailey and George S. Tavlas
}

\section{Introduction}

Since the move to a managed floating exchange rate system in 1973, world financial markets have been characterized by large movements in nominal exchange rates. These movements have been accompanied by large swings in real exchange rates, reflecting the fact that nominal exchange rate variations have not closely followed changes in relative prices of traded goods. The short-run variability of exchange rates-whether measured in real or nominal terms, in bilateral or effective terms-has been substantially higher in the post-1973 period than it was under the Bretton Woods system (Frenkel and Goldstein 1986). Moreover, exchange rate variations have been much greater than the early advocates of floating had expected. For example, in an influential article, Harry Johnson (1969, pp. 1920) argued that the allegation that a flexible-rate system would result in unstable rates ignored "the crucial point that a rate that is free to move under influences of changes in demand and supply is not forced to move erratically, but instead will move only in response to such changes in demand and supply ... and normally will move only slowly and predictably."'

Cato Journal, Vol. 8, No. 2(Fall 1988). Copyright (C) Cato Institute. All rights reserved.

Martin J. Bailey is an Economic Adviser to the Undersecretary for Economic Affairs at the Department of State and an Adjunct Professor of Economics at the University of Maryland. George S. Tavlas is an economist in the European Department of the International Monetary Fund. The authors are grateful to William Gavin, Peter Isard, Guy Stevens, Michael Ulan, and John Wilson for helpful comments. The views expressed are the authors' and are not to be interpreted as those of their respective institutions.

'Perceptively, Johnson (1969, p. 17) also recognized that exchange rates would be stable only as long as "underlying economic conditions (including government policies)" remained stable. 


\section{Cato Journal}

This paper assesses the causes of exchange rate variability and examines its consequences for trade and investment. Following John Williamson (1985), we distinguish between two concepts of variability -short-term volatility and longer-term misalignment. Volatility involves short-term (monthly, weekly, or even hourly) fluctuations in exchange rates as measured, say, by their absolute percentage changes during a particular period. In contrast, misalignment is a subjective concept and, as such, difficult to quantify. Misalignment has been defined as a departure over a substantial period of time of the exchange rate from its "fundamental equilibrium value" (i.e., the exchange rate that yields a cyclically adjusted current-account balance equal to normal private capital flows-those capital flows that exist in the absence of undue restrictions on trade and special incentives to incoming or outgoing capital) (Williamson 1985, Crockett and Goldstein 1987). For example, the value of the U.S. dollar in 1984 and early 1985 was considered by many commentators to be considerably higher than justified by the fundamentals; hence, the value of the dollar was perceived by these commentators as bound to come down. The problem with getting a grip on misalignment is, as Crockett and Goldstein (1987) have observed, the difficulty entailed in measuring such concepts as a "substantial" period of time, the "cyclically adjusted" current-account balance, "normal" private capital flows, "undue" restrictions on trade, and "special incentives" on capital flows.

The remainder of the paper discusses, in turn, the various explanations of exchange rate behavior, the effects of exchange rate variability, and the impact of exchange rate movements on U.S. exports and investment. We note that if exchange rate variability has been in some sense "excessive," it must have been unpredicted by theories of exchange rate determination, or at least inconsistent with the stylized explanations posited by those theories. Moreover, in considering the possible costs of exchange rate variability and misalignment, we observe that the main costs are usually associated with allocation effects on trade and investment; theoretically, the costs of exchange rate variability on trade and investment are ambiguous. Our empirical results of the effects of exchange rate variability on trade and direct investment in the U.S. economy do not support the hypothesis that exchange rate variations (defined in terms of either short-term volatility and longer-term misalignment) have hampered trade and investment in the U.S. economy.

\section{Explanations of Exchange Rate Behavior}

Why have exchange rates moved so much and for such long periods of time? In what follows, we will review six explanations of exchange 
rate behavior. Before doing so, however, several observations are in order.

The first pertains to the characterization of the present international exchange rate regime. At the outset, we described the current system as one of managed floating-not one of freely floating-currencies. This description is apt because most countries (almost all of which are developing countries) adhere to pegged exchange rate arrangements while a number of countries (including the eight members of the European Monetary System) follow limited flexibility visà-vis a single currency or group of currencies. ${ }^{2}$ Further, even among the floating currency countries, exchange rates have not been permitted to float cleanly, as evidenced by recent efforts to talk the U.S. dollar up or down (sometimes within the same day); by informal agreements among the Big Five (the Plaza Agreement, the Louvre Accord); and by large interventions of central banks. Indeed, intervention strategies have differed among countries and over time, ranging from free floating, to short-term smoothing, to heavy intervention aimed at achieving a targeted rate (Shafer and Loopeska 1983, p. 6).

The second observation is that the world operating environment since 1973 has differed substantially from that characterizing the Bretton Woods era. As Shafer and Loopeska argue, floating rates should not be blamed for the slowdown in world growth and trade that accompanied the move to managed floating. Specifically, they note that the rapid growth of the economies of Europe and Japan in the 1950s and 1960s was, in part, a catching up after World War II and was unlikely to be sustained, that the floating rate period inherited international disequilibrium and inflation, and that the world economy suffered two oil price shocks during the floating rate period. Also, the post-1973 period has been characterized by developments that contributed to exchange rate variability. These developments include the technological advances in communications that provide fast, high-volume linkages among world financial markets, enabling events in any one market to have an almost instantaneous impact on other markets. This rapid advance in communications technology has, not surprisingly, been accompanied by a relaxation of controls on capital movements.

Finally, as Frenkel and Goldstein (1986) note, exchange rates are financial asset prices and, therefore, are flexible and forward looking-unlike many goods prices that are sticky and backward looking

${ }^{2}$ See Tavlas (1987). However, as Goldstein (1984, pp. 3-4) reports, most of world trade is conducted at unpegged currencies. 
(reflecting previous contractural agreements). ${ }^{3}$ Volatility is to be expected in an auction market, such as the exchange market, under floating rates simply because of continuous surprises. William Nordhaus (1978, p. 250) made this point explicitly: "In those pure auction markets where prices are the main shock absorber, considerable price volatility is the result. These conditions generally prevail in raw foods and commodities markets, in markets for many financial instruments such as common stocks, or when a regime of pure floating exchange rates exists. Such volatility is an intrinsic feature of real world auction markets-markets in which there are incessant surprises due to weather, changes in taste, inventions, political upheaval, inflation, recession, and boom, etc." Indeed, Gottfried Harberler (1986, p. v) argues that the ability of flexible exchange rates to absorb shocks has eased quantity and price adjustments in goods and labor markets. Further, Maurice Obstfeld (1985) argues that it is doubtful whether the fixed exchange rate system would have survived the changed world environment since 1973 without the imposition of controls on capital movements and restrictions on trade.

The auction market characteristic is important, but it certainly does not account fully for the magnitude of exchange rate movements. To understand why instability may be an inherent characteristic of flexible rates, we turn to a brief overview of theories of exchange rate behavior.

A useful starting point for considering theories of exchange rate determination is the portfolio balance model. ${ }^{4}$ The model is built around the determinants of net outside supplies of stocks of assets denominated in different currencies and the demands for them. Individuals are assumed to allocate their wealth, which has a given total value at each moment, among alternative assets including, most generally, domestic and foreign money and domestic and foreign securities. Assets denominated in. different currencies are viewed by investors as perfect substitutes (i.e., uncovered interest rate parity holds). Thus, if one country has a higher expected monetary growth

\footnotetext{
${ }^{3}$ Frenkel and Goldstein (1986, p. 647) also point out that exchange rate changes have been smaller than changes in other asset prices, such as national stock markets and short-term interest rates.

'The portfolio balance model is an extension of the vintage 1970s' monetary model. As Krueger (1983, p. 50) observes, "At the present time it is difficult to distinguish an adherent of the monetary approach from the author of a portfolio balance model." An important bridge between the two approaches was provided in the article by Frenkel and Rodriguez (1975), which incorporated the treatment of asset accumulation and current account determination within the monetary approach. For an interesting appraisal of the monetary approach, see Boughton (1988).
} 
rate and consequently a higher expected inflation rate, assets denominated in its currency will carry an interest-rate differential that is equal to the expected depreciation in its exchange rate. Expectations play a key role in the determination of equilibrium. Another component of the portfolio model is that goods of different countries are essentially perfect substitutes, and there are virtually no barriers to instantaneous (price) adjustment in goods markets (see Krueger 1983, pp. 86-90). The assumptions with respect to both asset prices and goods prices will be relaxed below.

\section{Rational Speculative Bubbles}

By treating exchange rates as financial asset prices, the portfolio approach draws attention to the substantial influence of expectations. A number of writers including Mussa (1976), Frenkel and Mussa (1980), and Dornbusch (1980) have argued that the exchange rate market, as any asset market, is efficient; a market is considered to be efficient when prices reflect all available information, including expectations about economic policies. Consequently, the behavior of exchange rates is affected in an important way by new information that is continuously being processed by economic agents. Short-term fluctuations in exchange rates, according to the efficient markets view, are to be expected if the forces that lie behind exchange market equilibrium are themselves subject to substantial short-term fluctuation. As Michael Mussa (1976, p. 203) has stated, "under a floating exchange rate regime, private agents must continuously revise their expectations of the future behavior of money supplies and other relevant variables in forming their expectations about the appropriate level of the nominal exchange rate." Continuous revisions in expectations make for continually changing exchange rates. Indeed, if exchange rate variations were exclusively determined by new and unanticipated information, the exchange rate would follow a random walk-today's exchange rate would be the best predictor of expected future exchange rates.

One should note that if expectations are continuously revised in the same direction for a substantial period of time-for example, if expectations of interest rates are modified repeatedly in the direction of higher and higher rates, thereby reflecting an expected progressive tightening of monetary policy-the efficient markets view gives rise to what is referred to as rational speculative bubbles. Consequently, the efficient markets framework can account for both short-term volatility in exchange rates and longer-term movements, although the latter do not imply deviation from any fundamental equilibrium value. 


\section{Cato Journal}

\section{Irrational Speculative Bubbles}

The efficient markets view assumes that private agents process all information in a rational manner. Therefore, the market equilibrium exchange rate reflects the underlying economic fundamentals. By contrast, the irrational speculative bubbles story views economic agents as myopic. Ronald McKinnon (1976) had argued that exchange rate instability might be caused by an inadequate supply of private capital available for taking net positions in either the forward or spot markets on the basis of long-term exchange rate expectations. Thus, as Artus and Young (1979, p. 678) observed, the McKinnon hypothesis indicates that "cyclical variations in the demand for foreign exchange originating from trade or financial activities that may be sustained for a number of years may lead to large exchange rate movements because of a lack of investors with both the funds and the willingness to take a longer-run open position."

Paul Krugman (1985) has recently applied McKinnon's hypothesis to the context of the "high" value of the U.S. dollar of late 1984 and early 1985. According to Krugman (p. 106), "the case for a [speculative bubble] ... is in fact the argument that there is insufficient speculation." His argument runs as follows. The large U.S. trade deficits of the mid-1980s had produced a situation where the dollar was unsustainably high. The dollar was bound to fall in value, but investors' expectations were irrational. Had these expectations been rational, recognizing that the dollar needed (on the basis of long-run fundamentals) to come down, the expected future depreciation of the dollar would have inhibited the holding of dollar-denominated assets, thereby putting downward pressure on the dollar's value. Instead, market participants paid "more attention to the higher [relative] yield on dollar securities than to the forces which [would] eventually weaken the dollar. Thus, the dollar [was] high because investors [paid] too little attention to the prospect of future exchange rate changes, not too much" (Krugman 1985, p. 106). The market had reached a consensus that the dollar would come down slowly. If the long-term fundamentals pointed to the need for a rapidly falling dollar, then the market had overreacted to the then-existing interest differential because of a lack of forward-looking speculation, producing an irrational speculative bubble. Krugman used this argument to predict correctly that "the dollar must at some point plunge" (1985, p. 107). ${ }^{5}$ Assuredly Krugman's expectations proved to be more accurate than the representative market expectation. We are not sure,

${ }^{5} \mathrm{~A}$ hard landing was also predicted by Marris (1985). 
however, that this fact establishes that speculation was either irrational or insufficient.

\section{Overshooting: The Case of Sticky Prices}

Overshooting can occur in any portfolio model in which some markets do not adjust instantaneously. For example, Branson (1977), Dornbusch (1976), and Kouri (1976) have focused on the slow speed of price adjustment in the goods market to explain exchange rate instability; this focus reflects the view that goods prices are backward looking in the short to medium term while exchange rates are flexible and forward looking. The sticky price argument runs as follows: An unanticipated change in the nominal money supply produces an increase in the real quantity of money because prices do not adjust promptly. As a result, real interest rates fall, leading to an incipient capital outflow and a depreciation in the real exchange rate, which is proportionately more than the change in money (Dornbusch 1986 , p. 213). With lower real interest rates, the demand for goods picks up. In parallel, real exchange depreciation causes a substitution from foreign goods in favor of home country goods in both the domestic and export markets. Over time, as goods prices increase, the real money supply will contract and the real exchange rate will appreciate until real equilibrium is regained (Dornbusch 1986).

As Jeffrey Frankel (1985) has argued, if the market is foresighted, it anticipates that the expansion in demand will set prices in motion above their previously expected path. If we assume rational expectations, the anticipation of further exchange rate appreciation must be sufficient to offset the interest rate differential between domestic and foreign rates, so that opportunities for profits do not exist by holding either domestic or foreign assets. What accounts for the exchange rate overshooting is the fact that, following the monetary innovation, the exchange rate fell below the level that was expected in the long run (Frankel 1985, p. 7).

\section{Overshooting: The Case of Asset Accumulation}

Now we assume flexible goods prices but relax the assumption of perfect substitutability between domestic and foreign assets. Consequently, the variable that is not free to adjust instantanteously is the level of domestic claims on foreign assets. Next we assume, for purposes of illustration, an expansionary domestic fiscal policy leading to cumulative current-account imbalances. In the context of the Mundell-Fleming framework, the fiscal expansion results in a rise in domestic interest rates, an excess supply of foreign assets and an appreciation of the currency. Jeffery Frankel (1985) and Rudiger 


\section{CATO JOURNAL}

Dornbusch (1987) have shown that the accumulated net external indebtedness, which accompanies the current account deficits, will decrease the level of domestic claims on foreign assets, eventually undoing their initial excess supply and with it the appreciation of the domestic currency. But the currency will not just fall back to its original value because the current account deficits result in reduced income from net foreign assets. As Dornbusch (1987, p. 7) has argued: "The reduction in net external assets means that following a period of deficits, the current account cannot be balanced simply by returning to the initial real exchange rate. Now there will be a deficit from the increased debt service. Therefore, to restore current account balance, an overdepreciation is required."

Both of the overshooting hypotheses are able to account for exchange rate variability and long-term movements in rates. Short-term variability arises because both hypotheses emphasize the role of news. For example, as Artus and Young (1979, p. 679) observe with respect to the current account story: "Market participants-continually reassess their views of the needed exchange rate change on the basis of actual current balance developments without always being able to discount properly the effects of temporary divergences in economic cycles, J-curve effects of exchange rate changes, and so forth." Moreover, the fact that the overshooting hypotheses are able to explain short-term and long-term movements in the exchange rate should not be taken to imply that the exchange rate deviates in any way from its equilibrium value (Williamson 1985). Richard Levich (1985, p. 1018) makes this point explicitly: "[The] definition of overshooting draws a distinction between short-run and long-run equilibria while retaining the notion that the exchange rate is priced fairly at all times, a perfect reflection of all information."

\section{The Safe-Haven Hypothesis}

Michael Dooley and Peter Isard (1987) extend the portfolio balance model, focusing on international portfolio shifts. In particular, the safe haven approach "departs from other portfolio balance models of exchange rates by shifting attention away from the financial characteristics of assets. ... Instead, the approach emphasizes that variations over time in the prospective income streams on physical capital in different countries can generate changes in observed holdings of claims to those income streams, giving rise to desired net international capital flows and associated changes in relative prices and exchange rates" (Dooley and Isard 1987, p. 71). Consequently, the exchange rate is determined in such a manner as to give rise to a current account deficit that is equal to the rate at which foreigners 
wish to acquire claims on the domestic country. As such, the approach stresses the "safe-haven phenomenon" whereby the strength of the U.S. dollar in the first half of the 1980s is ascribed to the perceived relative strengthening of the U.S. economic and political situation. The transmission of such perceptions included a shift of bank lending from less-developed countries to the U.S. capital market and increased direct investment in the United States. One important implication of the safe-haven hypothesis is that "the choice between a fixed or flexible exchange rate regime may not have a very significant influence, ceteris paribus, on the variability of the real terms of international competition as characterized by the relative prices of tradable goods and the real balance of trade" (Dooley and Isard 1987, p. 79).

\section{Demand Shifts and Other Influences}

Alan Stockman (1987a, 1987b) provides a thorough, textbook-like review of explanations of exchange rate movements, summarizing most of the foregoing approaches and adding other detailed cases. His analysis includes shifts of demand in each country for internationally traded goods, plus other real shifts, but does not include irrational bubbles. He concentrates solely on shifts of fundamentals like those in the previous three cases just considered. The result adds to the richness and complexity of the issues we are considering, and it calls into question any approach that considers only one or two influences on exchange rates.

Stockman develops an equilibrium model of the determination of exchange rates and prices of goods. ${ }^{6}$ Changes in relative prices of goods, because of supply or demand shifts, induce changes in exchange rates and deviations from purchasing power parity. According to Stockman (1987a, p. 12), "Repeated disturbances to supplies or demands ... thereby create a correlation between changes in real and nominal exchange rates. This correlation is consistent with equilibrium in the economy, in the sense that markets clear through price adjustments."

A number of important policy inferences can be drawn from the equilibrium model of exchange rates. For purposes of this paper, the relevant inferences are that changes in exchange rates do not cause changes in relative prices but are themselves dependent variables driven by fundamentals (i.e., by exogenous variables). Further, the issue of whether exchange rate variability has detrimental effects on

\footnotetext{
${ }^{6}$ Disequilibrium theories of the exchange rate are based on sluggish adjustment of nominal prices and imply that the correlation between real and nominal exchange rate changes is exploitable by government interventions in the foreign exchange market (Stockman 1987a, p. 13).
} 
the economy-either through its effects on trade or investment-is not the relevant question "because the exchange rate is an endogenous variable. The right question is whether the underlying disturbances to the economy are 'good' or 'bad,' so (of course) the answer lies with the disturbance" (Stockman 1987a, p. 17). We would add that if "fundamentals" refer to consumer preferences, comparative advantage, other supply conditions, and comparative rates of inflation among different trading partners, then the associated changes in exchange rates are efficient (i.e., they increase world output). Whether these changes affect trade and investment (as they sometimes would) is less interesting than whether other changes in exchange rates affect trade and investment.

\section{Effects of Exchange Rate Variability}

In the light of the foregoing discussion of the causes of exchange rate volatility, we would prefer, so far as possible, to divide exchange rate changes into those caused by fundamentals and those caused by other factors (i.e., misguided speculation). Ideally, we would represent each such influence accurately by a right-hand-side variable in a regression; these variables would be exogenous, while exchange rates, trade, and investment would be a subset of the jointly determined (endogenous) variables of a comprehensive model. The regression, in that case, would be one of the reduced form equations, with, say, direct investment as the dependent variable. Besides the difficulty in trying to specify and measure the relevant exogenous variables, however, we are faced with the impossible task of finding a measure of the speculative influence. Consequently, we need a proxy for it, and the only proxy available is exchange rate variation not explained by the exogenous variables that represent fundamentals. Although this residual variability is not the fundamental cause of whatever effects we might observe in trade and investment, it can be viewed as the proximate cause, in its role as a proxy for misguided speculation. We can then address the question of what happens if governments adopt policies that stabilize exchange rates around the equilibrium rates determined by fundamentals. Would trade increase, and would international investment be larger or better allocated as a result? This approach has two clear advantages. First is the practical consideration just mentioned-that we can measure exchange rate variability whereas we cannot measure the amount of misguided speculation. Second, if all of the variability not explained by specified exogenous variables is due to irrational speculative bubbles or to other such causes, it is not clear that this variability should be con- 
sidered endogenous; there would be no prima facie reason to suppose that treating it as endogenous would bias the analysis. Of course, not all of the fundamentals can be measured, so that some bias may result from our approach; but we see no alternative.

In a recent paper with Ulan (Bailey, Tavlas, and Ulan 1987), we reviewed many of the arguments for and against the proposition that short-term exchange rate volatility reduces trade because of the risks and costs it involves. ${ }^{7}$ The argument that exchange rate volatility hampers trade is simple and almost self-evident: Because contracts to sell goods, movement of the goods themselves, and payments for them rarely all coincide, there will be an element of exchange risk in foreign trade. This risk is equivalent to a cost to a risk-averse trader, and the trader will sometimes bear an actual cost to avoid it. Although this cost may be small for short-term transactions (because transactions costs are low for foreign exchange), the bid-ask spread widens with volatility; also, forward exchange markets exist for only about a year or so into the future. Being like a transportation cost, in that exchange risk affects trade in both directions, exchange rate volatility will tend to reduce a country's exports and imports.

However, the arguments are not all on one side. For example, exporters may gain knowledge through trade that would help them anticipate future exchange rate movements better than can the average participant in the foreign exchange market. If so, the profitability of this knowledge could offset the risk of exchange rate volatility. If they wish to hedge longer-term investment or other transactions rather than use the forward exchange market, exporters can borrow and lend in local currency to offset their other commitments. For example, a plant in a foreign country can be financed mainly with local capital, so that investors limit their exchange risk in the basic investment. An additional counter-argument of especially great weight is that we have to specify the alternative to volatility. If the volatility is due to fundamental factors influencing the exchange rate, intervention by the authorities to reduce it would be unsustainable and eventually disruptive. To achieve a reduction of apparent, observed volatility, authorities would have to intervene with exchange controls or other restrictions on trade and payments. That intervention could be more harmful to trade, and reduce it more, than would unrestrained movement of the exchange rate.

Furthermore, volatility of a single exchange rate is a poor measure of the risk of trade with the country involved, because of portfolio considerations. In general, a firm will be involved in trade with

${ }^{7}$ See also Yeager (1976) for a discussion of the issue. 


\section{Cato Journal}

several countries and so will have a mixed portfolio of foreign claims and obligations. What additional exposure in one country adds to the risk of the portfolio depends both on the variability of the direct bilateral exchange rate and on its correlation with other exchange rates. Hence, the effect of exchange rate volatility on trade cannot be determined a priori, but is an empirical question.

If the effect of exchange rate volatility on trade is uncertain, the effect on investment flows is even more so. (In fact, we have found very little systematic published or unpublished discussion of this effect). Besides not being sure whether exchange rate volatility reduces trade, we cannot be sure, if it does, whether this effect would tend to increase or reduce international direct investment. A reduction in trade might mean more concentration on the home market by exporting firms, or it might mean that multinationals dispersed their production more completely into overseas markets and exported less from their major production plants in the home country. The first of these two cases would mean less international investment, presumably, whereas the second would mean more. This uncertainty augments the uncertainty resulting from the ambiguous effect of exchange rate volatility on trade.

This point came out clearly in a recent paper by David Cushman (1985), the one empirical article that we were able to find that deals with direct investment as a function of exchange rate volatility. Cushman notes that actual trade is more complex than simple models would suggest. Although a firm may export a good whose inputs consist exclusively of domestic goods and services, its trade may also involve intermediate goods in various ways. The effect of exchange rate volatility or other factors on the location of economic activity (i.e., on the location of value added) can, therefore, be complicated, which also complicates the analysis of investment flows. This consideration gives further scope for the effect to run in either direction.

Cushman's analysis emphasized, as did ours (Bailey, Tavlas, and Ulan 1987), that businesses or portfolio investors will balance risk against expected profit when they plan a transaction. Suppose, as Williamson (1985) suggests, that floating exchange rates result in significant "misalignments"-real exchange rates pushed out of line by temporary capital movements. Potential direct investors across national boundaries may share this view. Those who feel able to anticipate future changes of misaligned exchange rates will take this expectation into account in calculating expected and risk-adjusted rates of return (see Frankel 1985). If the profit expectation were uncorrelated with the risk, the effect of risk itself would be predictable for each transaction, taken separately. However, the Williamson 
argument is that misalignments are more frequent and more serious when exchange rates, freely floating, are volatile than when they are not. If so, risk will be positively correlated with expected profits for many transactions, so that the net effect is indeterminate until one has the specific numbers and the degree of risk aversion.

These points help highlight the central importance of the notion of misalignment to the analysis. If all variability of exchange rates were due to variation in the fundamentals, such as independent, unpredictable changes in monetary and fiscal policies in different countries, exchange rates would approximate a random walk. Without misalignment, there would be few opportunities for profitable anticipation, by traders or direct investors, of future exchange rate changes. Although some firms or households may believe that they can foresee shifts in such fundamentals, only in a few exceptional cases would the ability to do so be related to a firm's volume of foreign trade or investment. (Also, it would be harder to argue, as a rule, that the effects on trade and resource allocation, if any, of this type of exchange rate variability were harmful and distortive.)

Because it appears that "variability" has implicitly been almost synonymous with misalignment in much of the previous conceptual work on this issue, we have based our discussion on misalignment and on short-term volatility. With that approach, exchange rate variability can affect trade in either direction. Its effect on direct investment is still more uncertain, inasmuch as it could go in either direction even if the effect of variability were to reduce trade. With the consequences of both short-term volatility and misalignment on trade and investment conceptually uncertain, we turn to some empirical results concerning the effects of these two measures of exchange rate movements on trade and investment in the case of the United States.

\section{Exchange Rate Movements and U.S. Export and Investment Performance}

In recent years, a number of empirical studies dealing with the post-1973 period have been produced; they examine the issue of whether short-term exchange rate volatility hampers trade. Only one study has investigated the relationship between volatility and investment. To our knowledge, not a single empirical study has examined the effects of misalignment, per se, on either trade or investment.

Most recent empirical studies have supported the proposition that short-term volatility does indeed impede trade (Cushman 1983, Akhtar and Hilton 1984, Kenen and Rodrik 1986, Maskus 1986, Thursby and Thursby 1987, and De Grauwe and de Bellefroid 1987). The 
coverage of these studies has been impressive: It has encompassed both total and bilateral trade flows, differences in sampling data (i.e., time series and pooled time series cross-sectional), bilateral and trade-weighted measures of exchange rates, real and nominal exchange rates, and a range of industrial countries. Studies that have rejected the hypothesis that volatility has had an adverse impact on trade include the IMF (1984), Gotur (1985), and several papers with which we have been associated-Bailey, Tavlas, and Ulan (1986); Aschheim, Bailey, and Tavlas (1987); and Bailey, Tavlas, and Ulan (1987).

In the most comprehensive of our studies-Bailey, Tavlas, and Ulan (1987) - we tested for the impact of exchange rate volatility on real exports of 11 OECD countries, using for most countries two measures of volatility for both real and nominal exchange rates. ${ }^{8}$ In all, over the managed floating period we presented 33 regression equations. In addition to exchange rate volatility, the factors that were posited to affect exports of these countries were real GDP in partner industrial countries, real export earnings of oil-producing countries, and relative prices (defined as the ratio of the dollardenominated export unit values of each country relative to the dollar-denominated export unit values for the IMF's "industrial country" aggregate). Of the 33 regressions estimated, only 3 showed a significant and negative impact of volatility on exports. These 3 regressions each involved real volatility. So perhaps real volatility is the culprit. Considering only those equations with real exchange rate volatility variables, that still left only 3 instances out of 16 in which exchange rate volatility negatively and significantly affected real exports.

Despite the diversity of empirical results, some generalizations can be drawn from the current status of empirical work. First, most studies (including our work) that find a significant effect for volatility on trade find it only for real exchange rate volatility. But as our aforementioned results indicate, even in the case of real volatility, the evidence is anything but overwhelming. Second, of the studies that do find a negative effect of exchange rate volatility on trade, most do so using bilateral trade data (e.g., Cushman 1983, Akhtar and Hilton 1984, Maskus 1986, and Thursby and Thursby 1987). Thus it may be that volatility affects the pattern of trade, but not its overall level. Regarding the aggregate trade studies that find a negative impact of volatility on trade, Kenen and Rodrik (1986) examine the effects of exchange rate volatility on imports-not exports. Still, in

${ }^{8}$ The countries examined were Australia, Canada, France, Germany, Italy, Japan, the Netherlands, New Zealand, Switzerland, the United Kingdom, and the United States. 
only 4 of the 11 countries examined did the results show a negative and significant impact. On the other hand, De Grauwe and de Bellefroid (1987) find less ambiguous effects of volatility on exports. However, their study does not include a relative price term. In their words, "The reader may wonder why no relative price (or competitiveness) variables appear in the equation. The reason is that we concentrate here on the determinants of the long-run growth rates of trade.... Over very long periods ... these relative price effects are likely to have disappeared" (De Grauwe and de Bellefroid 1987, p. 195). The theoretical motivation behind this argument escapes us. At the very least, the effect of relative prices should have been empirically tested. By failing to do so, it is likely that the results obtained by De Grauwe and de Bellefroid comingled the effects of relative prices with exchange rate volatility, obtaining an exaggerated or spurious impact for the latter.

The final generalization to be drawn from empirical work is that the primary determinants of trade are real output in trading partner countries and the terms of trade. In this context, equations (1a), (1b), and (1c) in Table 1 provide estimates on the determinants of U.S. export volumes over the managed floating rate period. ${ }^{9}$ Equation (1a) shows that some 93 percent of the variance of real exports from the United States is explained by real output in other industrial countries, real export earnings of oil-exporting nations (a proxy for their ability to buy other nations' exports), and relative export prices between the United States and its industrial-country trading partners adjusted for exchange rate changes. (Thus, relative prices reflect real exchange rates in terms of traded goods. $)^{10}$ Equation (lb) adds the volatility of the real effective exchange rate to the previous specification. While the coefficient is negative, it is insignificant and does not change the coefficients of the other variables. Because the relative price term is adjusted for exchange rate changes, it may be that the relative price term is biasing the volatility coefficient toward zero. Accordingly, in equation (1c) we drop the relative price term while retaining the volatility term. The coefficient on the latter variable remains insignificant; meanwhile, the significance of the coefficients on the other

\footnotetext{
${ }^{9}$ Equations (la) through (Ic) are estimated over the quarterly period, 1975:1 through $1986: 1$. We began the estimation period in 1975:1 because exchange rate volatility is entered with an eight-period (i.e., two-year) lag, taking us back to 1973:1, the beginning of managed floating. We ended the estimation period in 1986:1, as export earnings of oil-exporting nations (a term in the equations) were available only through 1985:4. We were able to estimate that term through 1986:1, however, because it was entered with a one-quarter lag.

${ }^{10}$ See the notes to Table 1 for additional details.
} 
EFfects of Exchange Rate Variability on U.S. Export Volumes

\begin{tabular}{|c|c|c|c|c|c|c|c|c|c|c|}
\hline \multirow[b]{2}{*}{ Equation } & \multirow[b]{2}{*}{ Constant } & \multirow[b]{2}{*}{$\begin{array}{c}\text { Real OECD } \\
\text { GDP }\end{array}$} & \multirow[b]{2}{*}{$\begin{array}{c}\text { Relative } \\
\text { Export Prices }\end{array}$} & \multirow[b]{2}{*}{$\begin{array}{c}\text { Real Oil } \\
\text { Revenues }\end{array}$} & \multicolumn{2}{|c|}{$\begin{array}{c}\text { Exchange Rate } \\
\text { Variability }\end{array}$} & \multirow[b]{2}{*}{ Rho } & \multirow[b]{2}{*}{$\overrightarrow{\mathbf{R}}^{2}$} & \multirow[b]{2}{*}{ D.W. } & \multirow[b]{2}{*}{$\begin{array}{c}\text { Estimation } \\
\text { Period }\end{array}$} \\
\hline & & & & & $\begin{array}{l}\text { Short-Term } \\
\text { Volatility }\end{array}$ & $\begin{array}{l}\text { Long-Term } \\
\text { Misalignment }\end{array}$ & & & & \\
\hline (1a) & $\begin{array}{c}-2.46 \\
(3.0)\end{array}$ & $\begin{array}{l}1.05 \\
(7.9)\end{array}$ & $\begin{array}{r}-0.77 \\
(5.9)\end{array}$ & $\begin{array}{c}0.11 \\
(2.5)\end{array}$ & & & $\begin{array}{c}0.62 \\
(4.6)\end{array}$ & $0 . \overline{926}$ & 1.70 & $1975: 1-1986: 1$ \\
\hline (lb) & $\begin{array}{c}-2.23 \\
(2.6)\end{array}$ & $\begin{array}{l}1.02 \\
(7.0)\end{array}$ & $\begin{array}{c}-0.72 \\
(4.8)\end{array}$ & $\begin{array}{c}0.12 \\
(2.5)\end{array}$ & $\begin{array}{c}-0.84 \\
(0.7)\end{array}$ & & $\begin{array}{c}0.62 \\
(4.1)\end{array}$ & 0.923 & 1.75 & $1975: 1-1986: 1$ \\
\hline (lc) & $\begin{array}{c}0.70 \\
(0.4)\end{array}$ & $\begin{array}{c}10.55 \\
(1.9)\end{array}$ & & $\begin{array}{c}0.08 \\
(1.4)\end{array}$ & $\begin{array}{c}-1.64 \\
(0.9)\end{array}$ & & $\begin{array}{r}0.89 \\
(12.5)\end{array}$ & 0.900 & 1.73 & 1975:1-1986:1 \\
\hline (ld) & $\begin{array}{r}-2.18 \\
(1.9)\end{array}$ & $\begin{array}{l}1.01 \\
(5.5)\end{array}$ & $\begin{array}{r}-0.73 \\
(4.8)\end{array}$ & $\begin{array}{c}0.09 \\
(1.8)\end{array}$ & & & $\begin{array}{c}0.69 \\
(5.1)\end{array}$ & 0.908 & 1.65 & 1976:1-1986:1 \\
\hline (le) & $\begin{array}{c}-2.24 \\
(2.0)\end{array}$ & $\begin{array}{l}1.02 \\
(5.7)\end{array}$ & $\begin{array}{c}-0.78 \\
(4.3)\end{array}$ & $\begin{array}{c}0.09 \\
(1.8)\end{array}$ & & $\begin{array}{l}0.0005 \\
(0.4)\end{array}$ & $\begin{array}{c}0.67 \\
(4.8)\end{array}$ & 0.906 & 1.67 & $1976: 1-1986: 1$ \\
\hline (lf) & $\begin{array}{c}0.54 \\
(0.2)\end{array}$ & $\begin{array}{c}0.59 \\
(1.6)\end{array}$ & & $\begin{array}{c}0.04 \\
(0.7)\end{array}$ & & $\begin{array}{c}-0.0003 \\
(0.2)\end{array}$ & $\begin{array}{c}0.93 \\
(16.1)\end{array}$ & 0.889 & 1.44 & $1976: 1-1986: 1$ \\
\hline
\end{tabular}

NOTES: Numbers in parentheses are t-ratios. Real OECD is real GDP (current period) in national currency units for 11 industrial-country trading partners converted to U.S. dollars at 1985:1 exchange rates. Relative prices are the dollar-denominated export-unit value index divided by the IMF"s "industrial country" export-unit value series. Relative prices are entered with a two-quarter lag. Real oil revenues are the dollar value of oil exporters' export earnings (as provided by the IMF) deflated by the dollar-denominated export-unit value index of the "industrial nations" taken as a whole to represent the real purchasing power of the oil exporters as it relates to industrial-country exports. The figure is entered with a one-quarter lag. Short-term exchange rate variability is the absolute value of the quarterly percentage change in the real effective exchange rate (as constructed by Morgan Guaranty Bank). It is estimated by using an eight-period ( $t-1$ through $t-9)$ second-degree Almon lag. Long-term exchange rate misalignment is the deviation of the real effective exchange rate (REER) from the fundamental equilibrium exchange rate (FEER) as constructed by Williamson (1985). Williamson (1985) provides data on REER and FEER for the period 1976:1-1984:4. For 1985:1-1986:1, figures for REER and FEER have been updated by the authors, extrapolating data on the basis of figures contained in Williamson (1986). The export volume series (IMF) was seasonally adjusted using the X-11 ARIMA technique. Rho was estimated using a maximum likelihood procedure.

SourCES: IMF, International Financial Statistics; Morgan Guaranty Bank; Williamson (1985, 1986); and authors' calculations. 
remaining variables declines while serial correlation increases, suggesting a misspecification problem.

If short-term volatility of the exchange rate has not adversely affected U.S. exports over the managed floating period, what about exchange rate misalignment, defined as the difference between the real effective exchange rate (REER) and the real "fundamental equilibrium" exchange rate (FEER)? As Frenkel and Goldstein (1986) have noted, there is an assortment of problems associated with measuring an equilibrium exchange rate; any such measure is bound to be only an approximate one. Undaunted by the difficulties, Williamson (1986) provides estimates of the FEER and the REER over the period 1976:1 through 1984:4. We have updated Williamson's estimates of these two series by using data contained in Williamson (1986). The effects of deviations from the equilibrium exchange rate (i.e., REER minus FEER) are provided in equations (1d) through (1f). Equation (1d) is merely the specification in (1a), but it is estimated over the now shorter estimation period. Equation (le) adds the misalignment series; the misalignment variable is insignificant and has a positive coefficient. Finally, equation (1f) drops the relative price term while retaining the misalignment variable. The latter remains insignificant; meanwhile the properties of the equation (coefficients on other variables, serial correlation) deteriorate, again suggesting that misspecification results from dropping relative prices.

As noted, with the exception of Cushman (1985), empirical work dealing with the determinants of direct investment in the U.S. economy in recent years is nonexistent. ${ }^{11}$ Indeed, Cushman's paper dealt with bilateral direct investment outflows from the United States to five countries over the period 1963 through 1978; thus his data were drawn largely from the managed rate period. In Table 2 , we present results on the determinants of aggregate direct investment inflows into the United States over the quarterly interval, 1976:1 through 1986:1 (see the notes to Table 2 for the reason why we began with 1976:1). We test for the effects of short-term exchange rate volatility and long-term misalignment on real direct investment inflows.

We use a stock adjustment model to estimate the determinants of real direct investment-manipulation of the stock adjustment model results in a lagged dependent variable as one determinant of direct investment. In addition, we posit that direct investment is determined by the expected performance of the U.S. economy (proxied

\footnotetext{
${ }^{11}$ Cushman (1985, p. 298) observed that "empirical work concerning exchange rate uncertainty on direct investment is rare." The few studies that Cushman was able to find were published during the 1970s.
} 


\section{Effects of Exchange Rate Variability on Real Direct InVestment} IN THE UNITED STATES (1976:1-1986:1)

\begin{tabular}{|c|c|c|c|c|c|c|c|c|c|c|c|c|}
\hline Equation & Constant & $\begin{array}{c}\text { Anticipated } \\
\text { Real GDP }\end{array}$ & $\begin{array}{l}\text { Relative } \\
\text { Export } \\
\text { Prices }\end{array}$ & $\begin{array}{c}\text { Real } \\
\text { Interest } \\
\text { Rate Spread }\end{array}$ & $\begin{array}{c}\text { Lagged } \\
\text { Dependent } \\
\text { Variable }\end{array}$ & $\begin{array}{l}\text { Oil Shock } \\
\text { Dunmy }\end{array}$ & $\begin{array}{l}\text { Short-Term } \\
\text { Volatility }\end{array}$ & $\begin{array}{c}\text { Long-Term } \\
\text { Misalignment }\end{array}$ & Rho 1 & Rho 2 & $\overline{\mathbf{R}}^{2}$ & DW \\
\hline (2a) & $\begin{array}{c}-3.00 \\
(1.4)\end{array}$ & $\begin{array}{r}0.87 \\
(2.2)\end{array}$ & $\begin{array}{c}-2.95 \\
(3.1)\end{array}$ & $\begin{array}{c}0.08 \\
(2.0)\end{array}$ & $\begin{array}{c}0.54 \\
(3.2)\end{array}$ & $\begin{array}{r}0.21 \\
(1.4)\end{array}$ & & & $\begin{array}{c}-0.44 \\
(2.1)\end{array}$ & $\begin{array}{c}-0.40 \\
(2.1)\end{array}$ & 0.522 & 2.03 \\
\hline (2b) & $\begin{array}{r}-1.15 \\
(0.5)\end{array}$ & $\begin{array}{c}0.68 \\
(1.9)\end{array}$ & $\begin{array}{c}-4.00 \\
(3.3)\end{array}$ & $\begin{array}{l}0.14 \\
(2.4)\end{array}$ & $\begin{array}{c}0.49 \\
(3.0)\end{array}$ & $\begin{array}{c}0.35 \\
(2.1)\end{array}$ & $\begin{array}{l}9.45 \\
(1.4)\end{array}$ & & $\begin{array}{c}-0.55 \\
(2.7)\end{array}$ & $\begin{array}{r}-0.47 \\
(2.6)\end{array}$ & 0.555 & 2.08 \\
\hline (2c) & $\begin{array}{c}-3.39 \\
(1.1)\end{array}$ & $\begin{array}{l}0.81 \\
(1.6)\end{array}$ & & $\begin{array}{c}-0.04 \\
(0.9)\end{array}$ & $\begin{array}{l}0.63 \\
(3.0)\end{array}$ & $\begin{array}{r}0.17 \\
(0.8)\end{array}$ & $\begin{array}{c}-6.96 \\
(1.1)\end{array}$ & & $\begin{array}{c}-0.36 \\
(1.5)\end{array}$ & $\begin{array}{c}-0.28 \\
(1.3)\end{array}$ & 0.411 & 1.89 \\
\hline$(2 d)$ & $\begin{array}{r}-2.74 \\
(1.4)\end{array}$ & $\begin{array}{c}0.93 \\
(2.4)\end{array}$ & $\begin{array}{c}-4.35 \\
(3.5)\end{array}$ & $\begin{array}{l}0.06 \\
(1.3)\end{array}$ & $\begin{array}{c}0.45 \\
(2.5)\end{array}$ & $\begin{array}{r}0.27 \\
(1.8)\end{array}$ & & $\begin{array}{c}0.02 \\
(1.8)\end{array}$ & $\begin{array}{r}-0.41 \\
(1.8)\end{array}$ & $\begin{array}{c}-0.42 \\
(2.3)\end{array}$ & 0.566 & 2.16 \\
\hline$(2 e)$ & $\begin{array}{c}-2.00 \\
(0.7)\end{array}$ & $\begin{array}{c}0.72 \\
(1.3)\end{array}$ & & $\begin{array}{c}-0.03 \\
(0.4)\end{array}$ & $\begin{array}{l}0.53 \\
(1.9)\end{array}$ & $\begin{array}{r}0.28 \\
(1.3)\end{array}$ & & $\begin{array}{c}-0.001 \\
(0.1)\end{array}$ & $\begin{array}{c}-0.22 \\
(0.7)\end{array}$ & $\begin{array}{c}-0.20 \\
(0.8)\end{array}$ & 0.384 & 1.85 \\
\hline
\end{tabular}

NOTES: Numbers in parentheses are t-ratios. Dependent variable is nominal direct investment inflow into the United States (Federal Reserve Board's flow of funds series, seasonally adjusted) divided by the GDP deflator. Anticipated real GDP was constructed by regressing the logarithm of real U.S. GDP on its past values in periods t-1 through $t-13$, using a second-degree Almon polynomial distributed lag with no end-point restrictions. The predicted series made by that regression was used as the anticipated series. Relative export prices are the same series used in Table 1; as with the regressions contained in Table 1, the figure is entered with a two-quarter lag in the regressions reported above. Real interest rate spread is the differential between the real average market yield on U.S. government 10-year bonds (constant maturity) and the real average yield on long-term government bonds of major U.S. trading partners. The spread series is from Data Resources, Inc., U.S. model data bank. Because it is available beginning only in 1976:1, all of the above regressions were estimated beginning in 1976:1. The oil shock dummy variable is a shift dummy representing the second oil price shock. It equals unity from 1979:2 through 1980:2, and it equals zero for all other observations. The volatility and misalignment series are the same as used in the equations in Table 1 . Rho 1 and Rho 2 were estimated using a maximum The volatility and misalignment series are the same as used in the equations in Table 1 . Rho 1 and Rho 2 were estimated using a maximum likelihood procedure since the widely used Cochrane-Orcutt procedure results in inconsistent parameter estimates in the presence of lagged
dependent variables (see Aschheim and Tavlas 1988). We are grateful to John Wilson of the Federal Reserve Board for providing us with the nominal direct investment series.

Sources: Data Resources, Inc.; Federal Reserve Board; IMF, International Financial Statistics; Morgan Guaranty Bank; Williamson (1985, 1986); and authors' calculations. 
by "anticipated" real GDP in the United States), by real relative export prices (the same variable that was used in the equations for export volumes), by the real interest rate differential between longterm rates in the United States and those in the main trading partners of the United States, and by an oil shock term, which was aimed at capturing the effects of the oil price hike of the late 1970s. Through their effects on trade and investment, these variables also happen to be variables that help determine real exchange rates. With such variables in the equations, the regression coefficients for exchange rate variability and misalignment capture the effects of speculative errors for given fundamentals.

A general observation concerning the empirical results is that the explained proportions of the variances of the regressions are considerably below those obtained for the export equations. Equation (2a) presents our basic specification. Anticipated real GDP, the real interest rate spread series, and the lagged dependent variable all have positive (as expected) and significant coefficients. The oil price shock series also has a positive coefficient, but it is only marginally significant; the implication is that the oil price shock of the late 1970s increased direct investment into the United States either in accord with the safe-haven hypothesis or as part of the financing of the enlarged trade deficit. The relative price (real terms of trade) series has a negative coefficient (as expected) and is significant.

Equation (2b) tests for the impact of short-term exchange rate volatility on direct investment; the coefficient on the volatility variable is marginally significant-and positive. In equation (2c) we drop the relative price term in order to test whether its inclusion in equation (2b) was biasing the impact of the volatility term. (This is the same procedure that we undertook for the export equations.) The volatility term has a negative, but insignificant, coefficient in equation (2c). Finally, equations (2d) and (2c), with and without relative prices, respectively, test for the impact of the misalignment series. In equation (2d) the misalignment series is marginally significant, but with a positive coefficient. In equation (2e) it is negative and insignificant. In sum, we were unable to find any adverse impact of either exchange rate volatility or misalignment on real direct investment into the United States during the managed floating rate period.

\section{Conclusion}

We have argued that exchange rates vary both because of longterm fundamental influences and because of speculative and other transitory influences. These influences, especially the latter, are 


\section{Cato JournaL}

unpredictable, and they vary more sharply at some times than others. Consequently, the volatility of exchange rates is itself variable, and one can easily understand the rationale for an international policy regime that aims to reduce it.

To the extent that the size and variance of movements in exchange rates have been unpredictable, have they also been harmful? Advocates of fixed exchange rates posit that exchange rate variations are harmful because they entail resource allocation effects on trade and investment. For the U.S. economy, our results indicate that exchange rate variations have not had significant effects on trade and direct investment. Of course, we doubt whether a fixed exchange regime would have been able to survive during a period that has included huge disturbances, such as the two oil price shocks to the world economy. Our results on investment are exploratory and may be revised if progress should be made on the difficult specification problems involved. The issue is empirical and must eventually be resolved by testing the various claims against the data.

\section{References}

Akhtar, M., and Hilton, R. S. "Effects of Exchange Rate Uncertainty on German and U.S. Trade." Federal Reserve Bank of New York Quarterly Review 9 (Spring 1984): 7-16.

Artus, Jacques R., and Young, John H. "Fixed and Flexible Exchange Rates: A Renewal of the Debate." International Monetary Fund Staff Papers 26 (December 1979): 654-98.

Aschheim, Joseph; Bailey, Martin J.; and Tavlas, George S. "Dollar Variability, the New Protectionism, Trade, and Financial Performance." In The New Protectionist Threat to World Welfare. Edited by D. Salvatore. Amsterdam: North Holland, 1987.

Aschheim, Joseph, and Tavlas, George S. "Econometric Modelling of Partial Adjustment: The Cochrane-Orcutt Procedure, Flaws, and Remedies." Economic Modelling 5 (January 1988): 1-8.

Bailey, Martin J.; Tavlas, George S.; and Ulan, Michael, "Exchange Rate Variability and Trade Performance: Evidence for the Big Seven Industrial Countries." Weltwirtschaftliches Archiv 122 (1986): 466-77.

Bailey, Martin J.; Tavlas, George S.; and Ulan, Michael. "The Impact of Exchange Rate Volatility on Export Growth: Some Theoretical Considerations and Empirical Results." Journal of Policy Modeling 9 (Spring 1987): $225-43$.

Boughton, James M. "The Monetary Approach to Exchange Rates: What Now Remains?" International Finance Section Essays in International Finance. Princeton: Princeton University, 1988.

Branson, William H. "Asset Markets and Relative Prices in Exchange Rate Determination." Sozialwissenschaftlich Annalen I (1977): 69-89. 
Crockett, Andrew, and Goldstein, Morris. Strengthening the International Monetary System: Exchange Rates, Surveillance, and Objective Indicators. International Monetary Fund, Occasional Paper no. 50, 1987.

Cushman, David O. “The Effects of Real Exchange Rate Risk on International Trade." Journal of International Economics 15 (August 1983): 45-63.

Cushman, David. O. "Real Exchange Rate Risk, Expectations, and the Level of Direct Investment." Review of Economics and Statistics 67 (May 1985): 297-308.

De Grauwe, Paul, and de Bellefroid, Bernard. "Long-Run Exchange Rate Variability and International Trade." In Real Financial Linkages among Open Economies. Edited by Sven Arndt and J. David Richardson. Cambridge: MIT Press, 1987.

Dooley, Michael, and Isard, Peter. "Country Preferences, Currency Values, and Policy Issues." Journal of Policy Modeling 9 (Spring 1987): 65-82.

Dornbusch, Rudiger. "Expectations and Exchange Rate Dynamics." Journal of Political Economy 84 (December 1976): 1161-76.

Dornbusch, Rudiger. "Exchange Rate Economics: Where Do We Stand?" Brookings Papers on Economic Activity 1 (1980): 143-85.

Dornbusch, Rudiger. "Flexible Exchange Rates and Excess Capital Mobility," Brookings Papers on Economic Activity 1 (1986): 209-26.

Dornbusch, Rudiger. "Exchange Rate Economics: 1986." Economic Journal 97 (March 1987): 1-18.

Frankel, Jeffrey. Six Possible Meanings of "Overvaluation": The 1981-85 Dollar. Princeton Essays in International Finance. Princeton: Princeton University, 1986.

Frenkel, Jacob, and Goldstein, Morris. “A Guide to Target Zones.” International Monetary Fund Staff Papers 33 (December 1985): 633-73.

Frenkel, Jacob, and Mussa, Michael L. "The Efficiency of Foreign Exchange Markets and Measures of Turbulence." American Economic Review 70 (May 1980): 374-81.

Frenkel, Jacob, and Rodriguez, Carlos. "Portfolio Equilibrium and the Balance of Payments: A Monetary Approach." American Economic Review 65 (September 1975): 674-88.

Goldstein, Morris. The Exchange Rate System: Lessons of the Past and Options for the Future, International Monetary Fund, Occasional Paper no. 30, 1984.

Gotur, Padma. "Effects of Exchange Rate Volatility on Trade: Some Further Evidence." International Monetary Fund Staff Papers 32 (September 1985): 475-512.

Haberler, Gottfried. "The International Monetary System and Prospects for International Policy Coordination." American Enterprise Institute, Washington, D.C., December 1986.

International Monetary Fund. Exchange Rate Volatility and World Trade. Occasional Paper no. 29, 1984.

Johnson, Harry. "The Case for Flexible Exchange Rates, 1969." Federal Reserve Bank of St. Louis, Review 51 (June 1969): 12-24.

Kenen, Peter, and Rodrik, Davis. "Measuring and Analyzing the Effects of Short-Term Volatility in Real Exchange Rates," Review of Economics and Statistics 68 (May 1986): 311-15. 


\section{Cato Journal}

Kouri, Pentti. "The Exchange Rate and the Balance of Payments in the Short Run and in the Long Run." Scandinavian Journal of Economics 78, no. 2 (1976): 280-304.

Krueger, Anne O. Exchange Rate Determination. Cambridge: Cambridge University Press, 1983.

Krugman, Paul R. “Is the Strong Dollar Sustainable?” Federal Reserve Bank of Kansas City The U.S. Dollar-Recent Developments, Outlook, and Policy Options (August 1985): 103-32.

Levich, Richard M. "Empirical Studies of Exchange Rates: Price Behavior, Rate Determination, and Market Efficiency." In Handbook of International Economics, vol. 2. Edited by R. W. Jones and P. B. Kenen. Amsterdam: North Holland, 1985.

Marris, Stephen. Deficits and the Dollar: The World Economy at Risk. Washington, D.C.: Institute for International Economics, 1985.

Maskus, K. E. "Exchange Rate Risk and U.S. Trade: A Sectoral Analysis." Federal Reserve Bank of Kansas City, Economic Review 71 (March 1986): 16-23.

McKinnon, Ronald. "Floating Foreign Exchange Rates, 1973-74: The Emperor's New Clothes." In Institutional Arrangements and the Inflation Problem, vol. 3. Edited by Karl Brunner and Allen H. Meltzer. CarnegieRochester Conference on Public Policy. Amsterdam: North Holland, 1976.

Mussa, Michael. "The Exchange Rate, the Balance of Payments, and Monetary and Fiscal Policy under a Regime of Controlled Floating." Scandinavian Journal of Economics 78, no. 2 (1976): 229-48.

Nordhaus, William D. "Statement." In The Decline of the Dollar, pp. 24953. Hearings before the Subcommittee on Foreign Economic Policy. 95th Cong., 2d sess. Washington, June 1978.

Obstfeld, Maurice. "Floating Exchange Rates: Performance and Prospects." Brookings Papers on Economic Activity 2 (1985): 369-464.

Shafer, Jeffrey, and Loopeska, Bonnie. "Floating Exchange Rates after Ten Years," Brookings Papers on Economic Activity 1 (1983): 1-70.

Stockman, Alan C. "The Equilibrium Approach to Exchange Rates." Federal Reserve Bank of Richmond Economic Review 73 (March/April 1987a): 12-30.

Stockman, Alan C. "Exchange Rate Systems and Relative Prices." Journal of Policy Modeling 9 (Spring 1987b): 245-56.

Tavlas, George S. "Policy Aspects of Alternative Exchange Rate Regimes: Introduction." Journal of Policy Modeling 9 (Spring 1987): 1-5.

Thursby, J., and Thursby, M. "Bilateral Trade Flows, the Linder Hypothesis, and Exchange Risk." Review of Economics and Statistics 69 (August 1987): 488-95.

Williamson, John. The Exchange Rate System. Washington, D.C.: Institute for International Economics, 1985, revised.

Williamson, John. "Target Zones and the Management of the Dollar." Brookings Papers on Economic Activity 1 (1986): 165-74.

Yeager, Leland B. International Monetary Relations: Theory, History, and Policy, 2nd ed. New York: Harper and Row, 1976. 


\section{Reforming the Exchange Rate System Maurice Obstfeld}

The title of the paper by Martin Bailey and George Tavlas gives a somewhat inaccurate picture of its contents. Trade and investment performance is a key criterion for evaluating floating exchange rates since 1973, but the discussion and new empirical evidence related to this issue come only at the end of the paper. Instead, we find a broad survey covering the theory of floating exchange rates, speculative bubbles, and risk diversification. All these issues are central to the theory of how exchange rate variability affects trade, so the coverage given to them in the paper is appropriate. In my comment, I will go a step further than the authors and place their results in the context of the debate over reforming the exchange rate system.

\section{Arguments Against Floating}

When the move to floating took place over the 1971-73 period, it seemed a necessary temporary measure in the face of severe speculative pressures on the fixed exchange rate system. That "temporary" measure, however, turned out to be fairly permanent. It is in part the memory of the 1971-73 experience that has convinced most people that a return to rigidly fixed exchange rates is impracticable. Nevertheless, in recent years policymakers and economists increasingly have been asking whether there is a better way of running the exchange rate system, and whether possible improvements should involve limiting the flexibility of exchange rates.

The potential negative features of floating rates had been pointed out quite clearly before the early 1970s. These features were noticed during the interwar period and motivated the Bretton Woods conference to design a system based on fixed rates. The major arguments advanced against floating rates centered around five (overlapping) issues: discipline, the illusion of autonomy under floating rates, inter-

CatoJournal, Vol. 8, No. 2 (Fall 1988). Copyright (C) Cato Institute. All rights reserved. The author is Professor of Economics at the University of Pennsylvania. 
nationally uncoordinated policies, destabilizing speculation, and injury to international trade and investment.

\section{Discipline}

Fixed rates served as an automatic brake on overexpansionary monetary policies, since countries whose government policies led to balance-of-payments deficits would lose international reserves and soon be forced to adjust. Under floating rates this discipline would be absent.

\section{The Illusion of Autonomy under Floating Rates}

Proponents of floating argued that fixed rates restricted not only license (by imposing discipline) but also liberty. Foes of floating replied that it was unrealistic to think governments would really have greater freedom to set policies in a world of floating: The exchange rate's macroeconomic effects-on inflation, income distribution, industrial structure, and so on-are so important that no government, not even the U.S. government, can allow it to be a freely determined residual of monetary and fiscal policy choices.

\section{Internationally Uncoordinated Policies}

Just as governments had engaged in competitive currency depreciations between the world wars, a new era of floating might lead to economic policy warfare in which individual governments, pursuing nationalistic goals, might take mutually offsetting actions harmful to the international community.

\section{Macroeconomic Consequences of Destabilizing Speculation}

Critics of floating thought that speculators would not be a stabilizing influence on exchange rates, but would have the opposite effect, causing wild gyrations in their individual attempts to stay a step ahead of the market's psychology. These speculative rate movements, unrelated to market fundamentals, would destabilize the trade sector and the price level.

\section{Injury to International Trade and Investment}

A closely related fear was that excessive exchange rate variability would discourage the international flow of goods and capital.

\section{Would Fixed Rates Have Performed Better?}

Experience since 1973 has indicated that there is much truth in all of the negative forecasts of how floating rates would perform. What is less clear is how, and if, fixed rates would have performed better. 
Consider the discipline argument, for example. It makes little sense to blame exchange rate movements for resource misallocations when faulty policies lie behind the rate movements and the misallocations. One should still ask, however, whether less exchange rate flexibility would have promoted better policies. An affirmative answer is hard to support. Much recent strain in the world economy has been caused by the undisciplined increase in the federal fiscal deficit under the Reagan administration. Not only did this increase contribute to dollar overvaluation up until the dollar's about-face in early 1985 , it helped bring about the current stubborn pattern of trade imbalances that is a source of uncertainty and turbulence in the foreign exchange market and in other asset markets. But would less flexibility in dollar exchange rates have prevented this disastrous fiscal course? Almost certainly the answer is, No. ${ }^{1}$

Imagine, to take the most extreme case, a fixed dollar exchange rate. The immediate effect of the fiscal expansion would have been a large surplus in the U.S. balance of payments, hardly an event to discipline the United States. Had the Federal Reserve intervened to keep the dollar down-operations that would have led to a ballooning U.S. money supply - the result would have been inflation. This inflation would have become evident only a couple of years after the fiscal stimulus, but too late to have discouraged it. And we now would have the deficit and roaring inflation, had the Fed prevented the dollar's 1981-85 appreciation.

Alternatively, the European and Japanese central banks might have intervened to fix the dollar's exchange rate by shrinking their own money supplies. Such an approach would have been unsustainable for long, given the contractionary effect on foreign economies, and would have ended in a devaluation of their currencies against the dollar. It is hard to see why this action would have led America to modify its fiscal plans. The Johnson administration's post-1965 fiscal expansion, which many believe was the beginning of the Bretton Woods system's end, was certainly not restrained by the discipline of a fixed exchange rate.

One key caveat concerns the case in which a fiscal deficit is financed, not by borrowing, but by running the monetary printing presses. In this case a fixed exchange rate can impose discipline on fiscal policy, but once again, it need not. The current situation in Italy illustrates this point. Membership in the European Monetary System has led the Italian authorities to partially substitute bond issue for seigniorage in deficit financing. The necessity of limiting seigniorage has not

${ }^{1}$ See Obstfeld (1985). 


\section{Cato Journal}

tamed the deficit, however, and as a result, Italy's public debt has by now assumed alarming proportions.

The proposition that greater exchange rate variability has impeded the growth in international trade under floating rates has received very little solid empirical support, as Bailey and Tavlas document. At a very crude level, the trend growth rate of world trade in merchandise and services shows no noticeable decline after the early 1970s. Regression equations purporting to link trade volume measures to exchange rate variability yield conflicting conclusions and fail to be robust with respect to specification or choice of the variability measure. Even a reliably negative statistical correlation between variability and trade volume would be a very imperfect indicator of welfare effects. Under some circumstances international capital movements can substitute for trade, and in this connection there has been a large increase since the mid-1960s in the foreign sales of foreign affiliates of American firms. ${ }^{2}$

The lack of empirical support for the proposition that floating rates have impeded international trade is not surprising, because the theoretical case behind the proposition being tested by Bailey and Tavlas is slim. In particular, with regard to the impact of exchange rate variability on U.S. exports, it is unclear what the appropriate measure of the risk faced by exporters is, whether increased exchange rate variability necessarily increases that risk, and how exporters alter production and sales decisions when the risk they face increases.

Here I want to record, however, a disagreement with some arguments Bailey and Tavlas apparently make with regard to the resource misallocations that might arise under floating exchange rates. They seem to argue that the only exchange rate changes that give rise to resource misallocation are those that are not dictated by fundamentals such as monetary policy, fiscal policy, and demand conditionsonly such "spurious" exchange rate changes communicate the wrong price signals. This argument would be correct in an economy that functioned smoothly and efficiently in the absence of exchange market misbehavior. But that is not the world we live in.

Perhaps the most important market imperfection is the short-run stickiness of wages and the prices of many manufactured goods. ${ }^{3}$ In a sticky-price world, a rise in the demand for domestic money-one possible example of a change in a fundamental_causes the domestic currency to appreciate against foreign currencies, reducing domestic competitiveness and causing unemployment. This resource misal-

${ }^{2}$ The evidence is presented by Lipsey and Kravis (1987).

${ }^{3}$ Mussa (1986) makes a particularly convincing empirical case for price stickiness. 
location would not occur if the price level could fall immediately to help equilibrate the home money market; but the exchange rate change is completely justified by fundamentals, and it is necessary to prevent any abnormal profit opportunities from opening up in the foreign exchange market. ${ }^{4}$

In fact, one of the important criteria for choosing between exchange rate systems in a world of imperfect markets revolves around the nature of the shocks hitting the economy and the resulting role of the exchange rate in promoting or discouraging an efficient use of economic resources. If most shocks originate in asset markets-as in the example of a rise in the demand for money given above-fixed exchange rates indeed do better. Under a fixed rate, an increase in money demand, rather than appreciating the currency and causing unemployment, causes an inflow of capital that raises the home money supply in line with the money demand increase. If most shocks come from the economy's demand side, however (e.g., fiscal policy shifts or shifts in the demand for home exports), a floating rate generally promotes good resource allocations by partially offsetting these shocks. In the latter type of environment, a floating exchange rate could actually reduce the risk faced by exporters. Because their effects are felt throughout the economy, it is often hard to tell where the shocks that cause fluctuations originate, in the asset markets or in the output markets; but there is evidence that both types of shock have been important. This means that a significant degree of exchange rate flexibility is warranted.

\section{Exchange Rate Variability and Protectionism}

One important channel through which large misalignments under floating rates may lead to resource misallocations is ignored by the authors, but the channel is of great importance in our recent experience, and was perhaps the key factor in reversing the noninterventionist attitude toward exchange rates that the Reagan administration maintained until September 1985. Protracted swings in real exchange rates may strengthen the hand of those pressing the government for protection from foreign imports. While the problem is a political one, it certainly deserves attention and analysis in any study of the choice of exchange rate arrangements.

${ }^{4}$ This discussion does not deny, of course, that exchange rate changes unrelated to fundamentals can have adverse allocative effects. 


\section{Cato JOURnAL}

\section{The Credibility Problem}

A clear improvement in the functioning of the current exchange rate system would be a more cooperative mode of decisionmaking among the governments of the main industrial countries. It is far from clear, however, that such cooperation would optimally take the form of agreement on approximate exchange rate targets, the approach that apparently formed the basis of the February 1987 Louvre accord. Successive exchange rate agreements have lacked credibility in the face of persistent failures convincingly to rectify fiscal positions so as to hasten trade-balance adjustment. As exchange rate targets have been breached, governments have, in effect, looked to the market for guidance on "appropriate" exchange rate levels, while markets, in turn, have set exchange rates by trying to forecast official currency targets. Under the circumstances the market loses any anchor for long-run forecasts: Basically it is chasing its own tail. Noncredible exchange rate targets may be behind the extreme exchange rate volatility we have recently witnessed.

\section{Policy Imbalances and the Exchange Rate Puzzle}

Participants in the debate over floating rates, as well as future historians, face the puzzle of why currencies have been so much more volatile since the early 1980s. Circumstantial evidence certainly points to the unprecedented policy imbalances characterizing the period as a major part of the story. It does not help matters that these imbalances have occurred in a setting of rapid financial innovation, a setting in which the consequences of policies became unusually hard to predict. A credible commitment to more rigid exchange rates, if possible, would probably have reduced exchange rate instability. It is not at all clear, however, that such a commitment would have led to policies better than those that still await full correction. Nor is it clear how governments could have purchased again the credibility they so clearly lacked when the Bretton Woods system broke down.

\section{References}

Lipsey, Robert E., and Kravis, Irving B. "The Competitiveness and Comparative Advantage of U.S. Multinationals, 1957-1984.” Banca Nazionale del Lavoro Quarterly Review, no. 161 (June 1987): 147-65.

Mussa, Michael. "Nominal Exchange Rate Regimes and the Behavior of Real Exchange Rates: Evidence and Implications." In Real Business Cycles, Real Exchange Rates, and Actual Policies, pp. 117-214. Edited by Karl 


\section{COMMENT ON BAILEY/TAVLaS}

Brunner and Allan H. Meltzer. Carnegie-Rochester Conference Series on Public Policy 25. Amsterdam: North-Holland, 1986.

Obstfeld, Maurice. "Floating Exchange Rates: Experience and Prospects." Brookings Papers on Economic Activity 2 (1985): 369-450. 